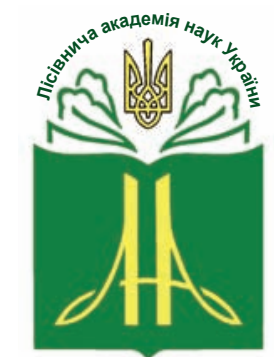

Forestry Academy of Sciences of Ukraine

Наукові праці Лісівничої академії наук України Proceedings of the Forestry Academy of Sciences of Ukraine

http://fasu.nltu.edu.ua https://doi.org/10.15421/412106

Article received 2021.01.12

Article accepted 2021.06.10
ISSN 1991-606X print

ISSN 2616-5015 online

(a) $\triangle$ Correspondence author

Yuriy Shparyk

yurii.shparyk@pnu.edu.ua

Halytska str., 201, Ivano-Frankivsk, 76008, Ukraine

УДК $630 * 228: 81$

\title{
Стан і структура пралісів Українських Карпат за результатами моніторингу
}

\author{
Ю.С. Шпарик' , В.П. Лосюк², А. В. Плига
}

Нещуодавні зміни у законодавстві щуодо ведення лісового господарства в пралісах, квазіпралісах і природних лісах, а також постійне підвищення изікавості науковців і громадськості до лісівничих особливостей пралісових екосистем призвели до необхідності ідентифікації таких лісів та організації пралісових пам'яток природи на всій території Украӥни. Основну частину цฺих науково-дослідних і законотворчих робіт виконано в межах проектів ГС «Всесвітній фонд природи Україна», за даними яких вже ідентифіковано близько 100 тис. га таких лісів, але изі дані постійно оновлюються. 3'ясовано, щзо в ичих лісах з 11 головних деревних видів переважають два (бук лісовий - 58 та ялина європейська - 33\%) і поширені шуе два (сосна гірська - 5 та ялиия біла - 3\%). Із великої кількості типів лісу (91 шт.) переважають волога чиста субучина (18\%) і бучина (18\%), волога чиста сусмеречина (13\%), вологий смерековий субір (6\%), волога буково-ялицева сусмеречина (6\%) і волога смерековоялицева субучина (5\%).

Значне різноманіття типів лісу і типів деревостанів у пралісах, квазіпралісах і природних лісах, потреба в контролі за рівнем антропогенного втручання зумовили розроблення нової методики моніторингу пралісів на основі результатів їх наукових досліджень, затверджених методик моніторингу лісів та ідентифікації пралісів. Розроблену методику апробовано в 2020 р. на шести об'єктах в Украӥнських Карпатах. Виявлено добрий стан таких лісостанів: найкращий в ялиновому пралісі, а найгірший - в ялиново-буково-ялицевому квазіпраліci, а також незначний антропогенний вплив на них (переважно інфраструктура і рекреація). Структура пралісів переважно складна і змінюється від умовно різновікового двоярусного букового квазіпралісу до різновікового чотириярусного кедрово-ялицево-ялинового пралісу.

Обгрунтовано потребу в щзорічному моніторингу пралісів з наукових і созологічних позицій для контролю за їх розвитком та антропогенним втручанням у изі екосистеми.

Ключові слова: головна порода; тип лісу; тип деревостану; мертва лежача деревина; природне поновлення; ярусність; життєвість; функціональність; товарність; протяжність крони.

\footnotetext{
Шпарик Юрій Степанович - член-кореспондент Лісівничої академії наук України, доктор сільськогосподарських наук, професор кафедри лісознавства. Прикарпатський національний університет імені Василя Стефаника, вул. Галицька, 201, м. Івано-Франківськ, 76008, Україна. Тел.: +38-0342-596163, +38-050-188-02-61. E-mail: yurii.shparyk@pnu.edu.ua ORCID: https://orcid.org/0000-00018047-6356

2 Лосюк Василь Петрович - член-кореспондент Лісівничої академії наук України, кандидат сільськогосподарських наук, науковий співробітник. Національний природний парк «Гуцульщина», вул. Дружби, 84, м. Косів, Івано-Франківська обл., 78600, Україна. Тел.: +03478-23709. E-mail: losyuk@i.ua ORCID: https://orcid.org/0000-0003-1807-1264

3 Плига Андрій Вікторович - координатор лісового напряму, ГС «Всесвітній фонд природи Україна», вул. Раїси Окіпної, 4, офіс 170, м. Київ, 02002, Україна. Тел.: +38093-3495281. E-mail: aplyha@wwf.ua
} 
Вступ. Ключове значення пралісів для ідентифікації природної структури лісів та їх динаміки, як основи для розроблення лісівничих стратегій за типами лісу, відоме вже не одну сотню років (Gurnaud, 1886; Gayer, 1898; Engler, 1900; Biolley, 1901; Zlatník, Korsuň, Kočetov, Kseneman, 1938). В Україні ці природні еталони стійкості та продуктивності раніше широко використовували для розроблення базових понять лісівничої науки (Висоцкий, 1916; Алексеев, 1928; Докучаев, 1949; Погребняк, 1968), а на сьогодні - для ідентифікації напрямів змін у лісових екосистемах у сучасних природно-кліматичних умовах та розроблення шляхів їх адаптації до цих змін (Korpel, 1995; Стойко, 2006; Ю.С. Шпарик, Коммармот, Беркела, 2010; Ю.С. Шпарик, Криницький, Дебринюк, 2020; Ю.С. Шпарик, Вітер, В.Ю. Шпарик, 2020; Дідух, Чорней, Буджак, 2016). Тому праліси завжди були пріоритетними об'єктами досліджень у лісівничій науці.

Зацікавленість суспільства до пралісів суттєво підвищилася після 2007 р., коли українські букові праліси Карпат було віднесено до об'єктів Всесвітньої природної спадщини ЮНЕСКО (разом зі словацькими кластерами букових пралісів). Це єдиний природний об'єкт України у спадщині ЮНЕСКО (UNESCO, 2007). Надалі цей об'єкт тільки розширявся (у 2011 р. - на стародавні букові ліси Німеччини, у 2017 p. - на стародавні букові ліси в 9-ти європейських країнах і на додаткові кластери в Україні), тому цікавість до пралісів стала загальноєвропейською тенденцією. Відповідно збільшилась кількість наукових публікацій щодо функцій і властивостей пралісів (Pittner, \& Saniga, 2008; Brang et al., 2014; Schütz, Saniga, Diaci, \& Vrška, 2016; EUROPARC, 2017; Machar et al., 2017; Zenner, Lynn, Pecka, Hobi, 2020).

Україна підтримала таке стрімке посилення цікавості до пралісів у законодавчій площині з урахуванням результатів наукових досліджень: у 2017 р. ухвалено Закон України «Про внесення змін до деяких законодавчих актів України щодо охорони пралісів згідно з Рамковою конвенцією про охорону та сталий розвиток Карпат»; у 2018 р. - «Методику визначення належності лісових територій до пралісів, квазіпралісів і природних лісів» та «Методику визначення належності територій до пралісових пам'яток природи». Це дало змогу офіційно ідентифікувати праліси в Україні, погодити їх наявність 3 користувачами лісів і розпочати створення відповідних об'єктів ПЗФ - пралісових пам'яток природи. Основний обсяг цих робіт виконали експерти і працівники ГС «Всесвітній фонд природи Україна». Робота в цьому напрямі триває, а актуальна інформація про неї є на сайті організації у форматі ГІС (рис. 1 (WWF Ukraine, 2021)). Станом на 2020 р. в Україні всіма експертами виявлено 97 тис. га пралісів, квазіпралісів і природних лісів, зокрема майже 50 тис. га - пралісів. Найбільше таких лісів у Закарпатській - 63, Івано-Франківській 21 та Чернівецькій - 7 тис. га областях. В інших областях виявлено окремі кластери таких лісів: Во- линська - 1,4; Львівська - 0,7; Житомирська - 0,6; Рівненська - 0,6; Чернігівська - 0,3; Сумська - 0,2; Київська - 0,1 тис. га (Y.S. Shparyk et al., 2019; WWF Ukraine, 2019). Отже, в Україні офіційно виявлено достатньо значні площі пралісів і квазіпралісів, які зафіксовані в натурі і потребують контролю (моніторингу) за їхнім станом.

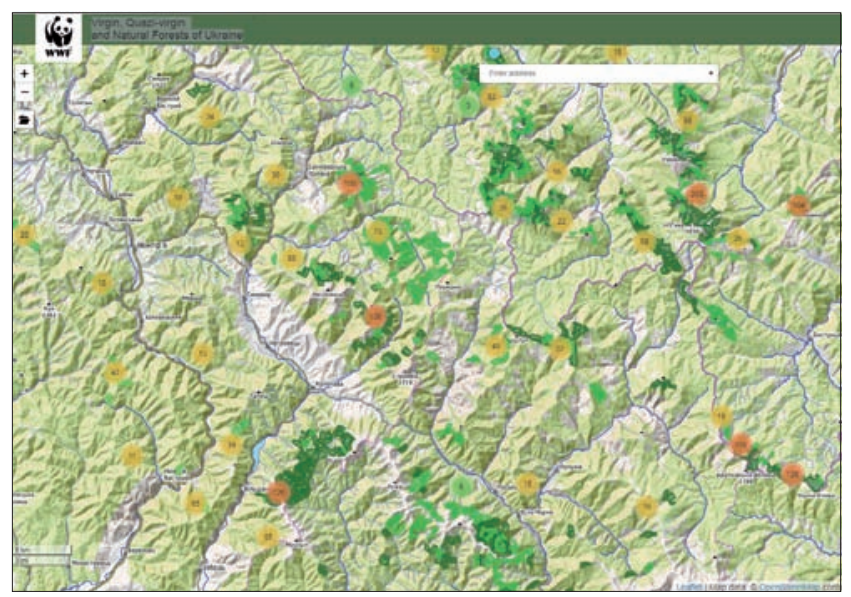

Рис. 1. Фрагмент онлайн ГІС пралісів України на сайті WWF Україна (WWF Ukraine, 2021)

Навіть за відсутності прямого антропогенного втручання, праліси постійно перебувають під впливом зовнішніх природних чинників, які в комплексі з особливостями внутрішнього їх розвитку і формують актуальний на сьогодні стан пралісів. Найсуттєвіше на стан пралісів впливають два зовнішніх чинники: глобальні зміни клімату, які змінюють лісорослинні умови, що впливає на конкурентоздатність деревних видів і може призвести до зміни породного складу пралісу (Jump, Hunt, \& Peñuelas, 2006; Дідух, Чорней, Буджак, 2016; Shukla et al., 2019; Ю.С. Шпарик, Криницький, Дебринюк, 2020 ); стихійні явища (вітровали і сніголами), які можуть зруйнувати верхні яруси пралісу на значних площах (Молотков, 1966, Korpel, 1995; Калуцький, Олійник, 2007; Janda et al., 2014; Ю. С. Шпарик, Biтер, В. Ю. Шпарик, 2020). Зміни стану пралісів стаються і під впливом внутрішніх чинників - на різних стадіях розвитку структура пралісів може змінюватися в значних межах (Standovár, \& Kenderes, 2003; Ю.С. Шпарик, Коммармот, Беркела, 2010; EUROPARC, 2017; Zenner, Lynn, Pecka, Hobi, 2020). Викладені вище дані однозначно вказують на потребу в контролі за станом пралісів в Україні, що можна реалізувати методами моніторингу лісів.

Об'єкти та методика досліджень. У статті 35 Лісового кодексу України зазначено, що організація лісового господарства передбачає зокрема і ведення моніторингу лісів, а в ст. 55 констатовано, що моніторинг лісів - це система регулярного спостереження, оцінювання і прогнозування динаміки кількісного та якісного стану лісів, яка є складовою частиною державної системи моніторингу навколишнього природного середовища. На жаль, у Лісовому кодексі немає чіткої регламентації позиції, хто і за які кошти повинен здійснювати моніторинг 
лісів, а тому останніми роками ці роботи виконують тільки фрагментарно. Зрозуміло, що у контексті збереження пралісів на перше місце під час моніторингу виходить контроль антропогенного втручання у процеси росту і розвитку пралісів.

Об 'єкт досліджень - праліси Українських Карпат різних природних зон у контексті їх стану і структури. Предмет дослідження - стан з позицій наявності пошкоджень елементів пралісів та структура з позицій наявності і розташування елементів пралісів залежно від їх породного складу та розташування цих лісових ділянок. Мета досліджень ідентифікувати стан і структуру пралісів Українських Карпат, здійснити контроль за наявністю та інтенсивністю антропогенного впливу на них.

Потрібно відзначити дуже високе різноманіття ідентифікованих в Україні пралісів, квазіпралісів і природних лісів за віком, породним складом, типами лісу та інше. Зокрема, в Українських Карпатах експерти ГС «Всесвітній фонд природи Україна» (за винятком лісів Львівської обл.) ідентифікували в таких лісостанах 11 головних порід (рис. 2) у 91 типі лісу (рис. 3) 47-ми підприємств різних відомств, а варіантів породного складу - близько сотні. Для врахування такого високого різноманіття та потреб контролю за антропогенним втручанням було розроблено спеціальну методику для моніторингу пралісів, основні положення якої такі:

- об'єкт моніторингу пралісів закладають у вигляді кругової площадки площею $1000 \mathrm{~m}^{2}$ з розрахунку - один об’єкт на 1 тис. га пралісів (квазіпралісів і природних лісів) однієї головної породи у найпоширенішому типі лісу, але не менше одного об'єкта на підприємство для кожної головної породи (див. рис. 2 і 3);

- об'єкти моніторингу обстежують один раз на п'ять років наприкінці вегетаційного періоду - залежно від природної зони України це може бути серпень або вересень, але повторно потрібно обстежувати в той самий період ( \pm 1 тиждень);

- основні види робіт: внесення (контроль) загальної інформації, контроль критеріїв та індикаторів пралісів, контроль антропогенного втручання.

Для внесення загальної інформації про об'єкт моніторингу пралісів визначали такі показники: прив'язка до актуальної квартально-видільної мережі за підприємствами та їх відділеннями; виконавці; дата обстеження; лісівничо-таксаційні показники конкретної лісової ділянки за даними останнього лісовпорядкування; рік останнього лісовпорядкування; здійснені заходи (назва, рік, обсяг, № документа); заплановані заходи (назва, рік, обсяг). Контроль критеріїв та індикаторів пралісів здійснювали за міжнародною методикою їх інвентаризації, яка має успішну адаптацію в Україні з 2000 р. (Ю. С. Шпарик, Коммармот, Беркела, 2010), а перелік критеріїв та індикаторів взято 3 «Методики визначення належності лісових територій до пралісів, квазіпралісів і природних лісів» (Мінприроди України, 2018).

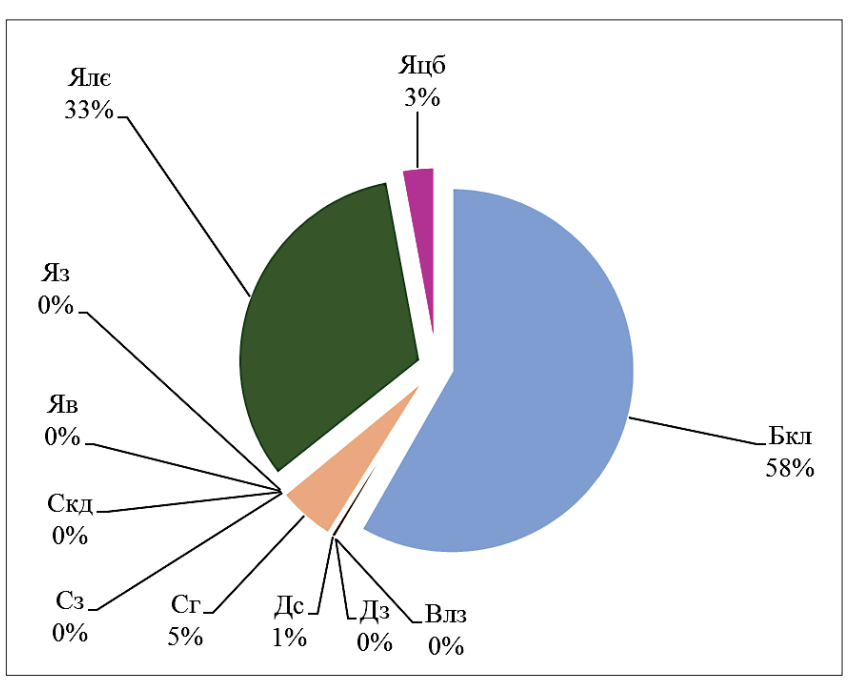

Рис. 2. Різноманіття головних порід ідентифікованих пралісів та квазіпралісів Українських Карпат (WWF Ukraine, 2021)

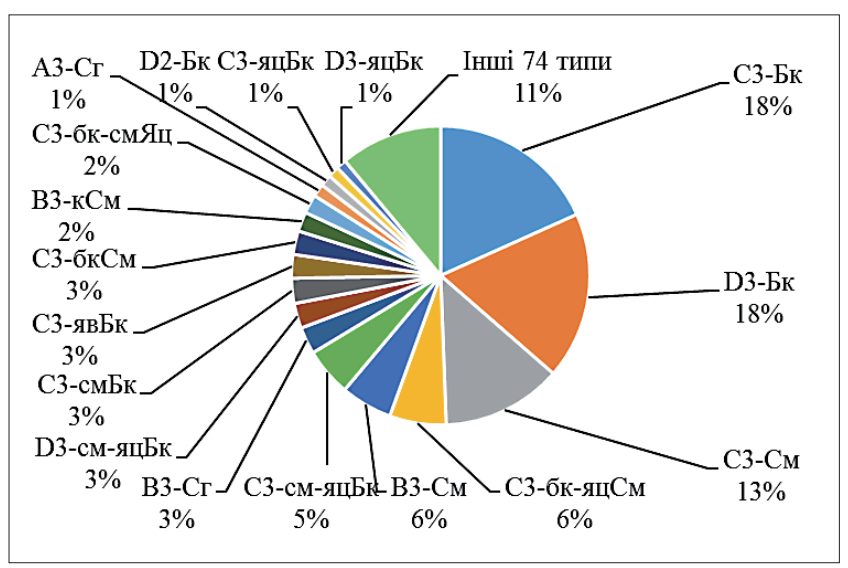

Рис. 3. Різноманіття основних (> $1 \%$ за площею) типів лісу ідентифікованих пралісів та квазіпралісів Українських Карпат (WWF Ukraine, 2021)

Позначення на рис. 2 і 3: бк, Бк - Fagus sylvatica L.; БП - Betula pendula Roth.; Влз - Alnus viridis D.C.; Дз - Quercus robur L.; Дс - Quercus petraea Matt.; к, Скє - Pinus cembra L.; Кля, Яв Acer pseudoplatanus L.; $\mathrm{C}_{\Gamma}-$ Pinus mugo L.; см, См, Ял - Picea abies (L.) Karst.; яц, Яц - Abies alba Mill.

Контроль антропогенного втручання в екосистему пралісу здійснено за такими його видами: штучне лісовідновлення, розвиток інфраструктури, побічне користування, використання лісової підстилки, випас худоби, рекреаційне використання, інші види користування. Виконано також картування дерев і фотофіксацію стану пралісів від центру об’єкта в напрямі основних сторін світу. Відзначимо, що ми підготували детальну методику моніторингу пралісів, квазіпралісів і природних лісів 3 відповідними бланками, передано ії на обговорення y WWF Україна і подальшого затвердження

Результати та обговорення. У 2020 р. підготовлену нашу методику моніторингу пралісів, основні положення якої викладено вище, було апробовано на шести об'єктах моніторингу в трьох облас- 
тях України: у Закарпатті - на державних підприємствах «Рахівське ЛДГ» та «Свалявське ЛГ»; у Прикарпатті - на ДП «Делятинське ЛГ» та «Осмолодське ЛГ»; у Буковині - на ДП «Берегометське ЛМГ» та «Сторожинецьке ЛГ». Середні лісівничотаксаційні показники обстежених об'єктів моніторингу (табл. 1) підтверджують результати ідентифікації пралісів щодо значного різноманіття структури їх деревостанів. Породний склад деревостанів на об'єктах моніторингу пралісів переважно відповідає типу лісу, а основні головні породи регіо- ну (бук, ялина, ялиця) представлені разом на двох об'єктах. Кількість дерев на об'єктах змінюється від 200 до 900 шт. га ${ }^{-1}$, середній діаметр - від 21 до 38 см, середня висота - від 17 до 28 м, сума площ поперечного перерізу - від 38 до $68 \mathrm{~m}^{2} \cdot \mathrm{ra}^{-1}$, запас деревини - від 570 до 938, а запас сухостою - від 0,5 до $101 \mathrm{~m}^{3} \cdot \mathrm{ra}^{-1}$. Отже, є підстава стверджувати, що моніторингом охоплено достатньо широкий спектр типів деревостану, а встановлені показники відповідають регламентованим критеріям та індикаторам пралісів.

\section{Лісівничо-таксаційні показники деревостану на об'єктах моніторингу}

Таблиияя 1

\begin{tabular}{|c|c|c|c|c|c|c|c|}
\hline $\begin{array}{c}\text { Індекс типу } \\
\text { лісу }\end{array}$ & Склад & $\begin{array}{c}\text { Кількість } \\
\text { дерев, } \\
\text { шт. } г \mathrm{a}^{-1}\end{array}$ & $\begin{array}{c}\text { Середній } \\
\text { діаметр, см }\end{array}$ & $\begin{array}{c}\text { Середня } \\
\text { висота, } \\
\text { м }\end{array}$ & $\begin{array}{c}\text { Сума площ } \\
\text { поперечного } \\
\text { перетину, } \text { м }^{2} \text { га }{ }^{-1}\end{array}$ & $\begin{array}{c}\text { Запас } \\
\text { стовбурової } \\
\text { деревини, } \text { м }^{3} \cdot \mathrm{ra}^{-1}\end{array}$ & 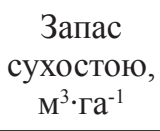 \\
\hline \multicolumn{8}{|c|}{ квазіпраліс у лісфонді ДП «Берегометське ЛМГ» } \\
\hline $\mathrm{C}_{3}$-бк-смЯц & 9Яц1Ял + Бк & 804 & 27,5 & 23,0 & 60,8 & 789 & 60 \\
\hline \multicolumn{8}{|c|}{ квазіпраліс у лісфонді «Делятинське ЛГ» } \\
\hline $\mathrm{D}_{3}$-бк-смЯц & $\begin{array}{c}\text { 7Яц2Бк1Ял + } \\
\text { Кля }\end{array}$ & 784 & 26,5 & 23,0 & 54,0 & 938 & 0,5 \\
\hline \multicolumn{8}{|c|}{ праліс у лісфонді «Осмолодське ЛГ» } \\
\hline $\mathrm{C}_{3}-\mathrm{CM}$ & $\begin{array}{l}\text { 7Ял1Яц } \\
\text { 1Скє1Бп }\end{array}$ & 904 & 21,2 & 17,0 & 38,2 & 353 & 19 \\
\hline \multicolumn{8}{|c|}{ праліс у лісфонді «Рахівське ЛДГ» } \\
\hline $\mathrm{C}_{3}-\mathrm{CM}_{\mathrm{M}}$ & 10Ял+Яв & 271 & 36,3 & 28,0 & 48,6 & 739 & 77 \\
\hline \multicolumn{8}{|c|}{ квазіпраліс у лісфонді «Свалявське ЛГ» } \\
\hline $\mathrm{C}_{3}$-Бк & 10Бк & 211 & 38,2 & 25,0 & 46,9 & 571 & 38 \\
\hline \multicolumn{8}{|c|}{ праліс у лісфонді «Сторожинецьке ЛГ» } \\
\hline $\mathrm{C}_{3}$-см-яцБк & 7БкЗЯц & 322 & 38,3 & 27,0 & 50,7 & 775 & 101 \\
\hline
\end{tabular}

За результатами дослідження кедрово-ялицевоялинового пралісу в лісфонді ДП «Осмолодське ЛГ» виявлено невідповідність породного складу лісостану та показників грунту до встановленого лісовпорядкуванням тут типу лісу - вологої чистої сусмеречини. Поглиблене вивчення видового складу трав'яного вкриття (за домінування Vaccinium myrtillus L. та Vaccinium vitis-idaea L.), природного поновлення і типу грунту (на всій ділянці - виходи скельних порід) дають підставу говорити про помилку в ідентифікації на цій лісовій ділянці типу лісу. За результатами досліджень, тип лісу на ділянці можна ідентифікувати як вологий кедровосмерековий субір (рис. 4).

За розподілом кількості дерев і запасу деревини за ярусами деревостану встановлено, що його структура на всіх трьох об'єктах моніторингу є триярусною і характеризується різновіковістю, тоді як квазіпралісові лісостани $є$ переважно двоярусними та умовно різновіковими, за винятком об'єкта у лісфонді ДП «Берегометське ЛМГ» - тут буковоялиново-ялицевий квазіпраліс має різновікову триярусну структуру і характеризується різновіковіс- тю. Так, усі чотири об’єкти представлені трьома ярусами, проте в ялиново-буково-ялицевому квазіпралісі мало дерев у другому ярусі, а в буковому квазіпралісі - у третьому ярусі (рис. 5). При цьому співвідношення кількості дерев за ярусами тільки на двох об'єктах відповідає спадному типу розподілу дерев за діаметром, який характерний для пралісів - в ялиново-буково-ялицевому квазіпраліci i в ялицево-буковому пралісі. Результати попередніх наших досліджень свідчать, що така ситуація пов'язана 3 малою площею пробної ділянки, яка не дає змоги повністю охопити площу навіть однієї стадії розвитку пралісів, бо вона може бути більшою ніж гектар (Шпарик, Коммармот, Беркела, 2010).

Подібні тенденції спостережено і щодо запасу деревини - вона представлена певними обсягами у всіх ярусах, але іiі запаси в третьому ярусі ялинового пралісу і букового квазіпралісу незначні через низькі таксаційні показники дерев третього ярусу на цих об'єктах (рис. 6). При цьому, запас стовбурової деревини має значну мінливість - від 353 у кедрово-сосново-ялицево-ялиновому пралісі до 
938 м $^{3}$ га ${ }^{-1}$ в ялиново-буково-ялицевому квазіпралісі (див. табл. 1), що можна пояснити різними лісорослинними умовами (у першому випадку - це вологий субір, а в другому - вологий груд) та різними стадіями розвитку пралісів на об’єктах моніто-

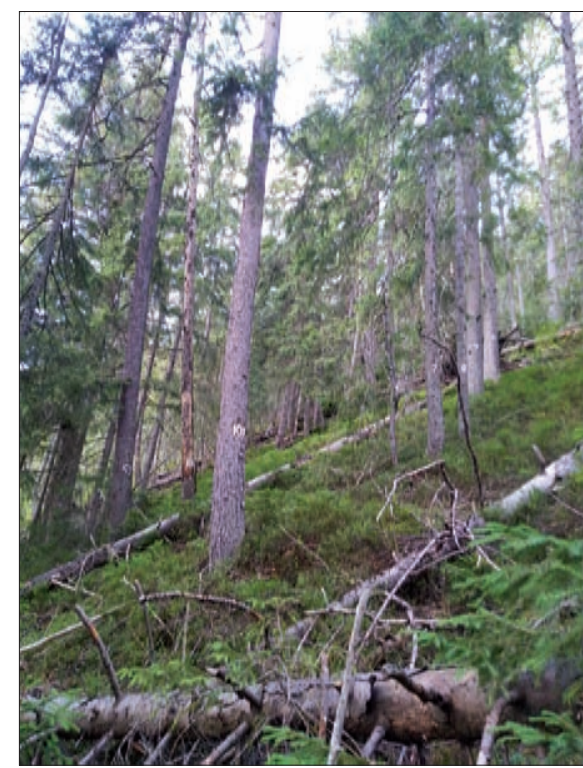

а) у напрямку на північ; рингу (у першому випадку - це стадія розпаду, а в другому - стадія стиглості). Якщо не брати до уваги мінімальне і максимальне значення, то запаси деревини в пралісах становлять в середньому від 600 до $800 \mathrm{M}^{3} \cdot \mathrm{ra}^{-1}$.

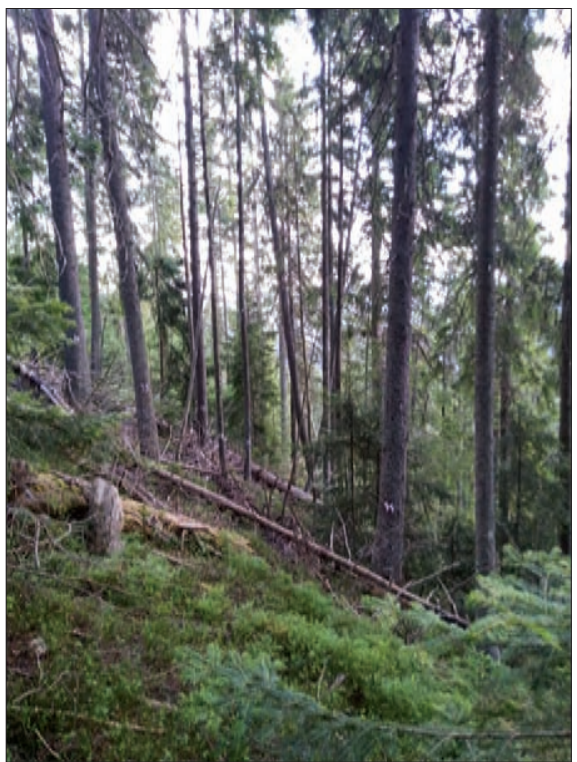

б) у напрямку на південь;

Рис. 4. Фрагменти об’єкта моніторингу на ділянці кедрово-ялицево-ялинового пралісу (фото Ю. С. Шпарика)

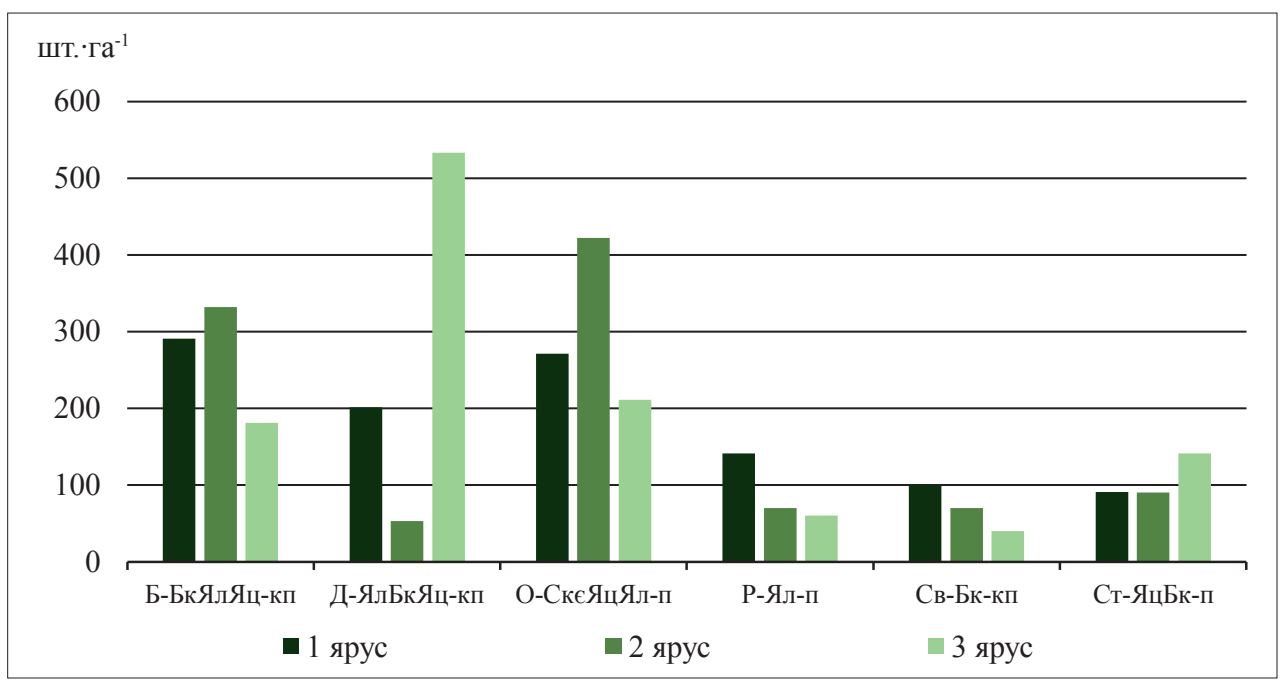

Рис. 5. Розподіл кількості дерев за ярусами пралісів та квазіпралісів Українських Карпат (умовні позначення об’єктів моніторингу на рис. 5-8 і в табл. 2 і 3: Б-БкЯлЯц-кп - буково-ялиново-ялицевий квазіпраліс у лісфонді ДП «Берегометське ЛМГ»; Д-ЯлБкЯц-кп - ялиново-буково-ялицевий квазіпраліс у лісфонді ДП «Делятинське ЛГ»;

О-СкеЯцЯл-п - кедрово-сосново-ялицево-ялиновий праліс у лісфонді ДП «Осмолодське ЛГ»; Р-Ял-п - ялиновий праліс у лісфонді ДП «Рахівське ЛДГ»; Св-Бк-кп - буковий квазіпраліс у лісфонді ДП «Свалявське ЛГ»; Ст-ЯцБк-п - ялицево-буковий праліс у лісфонді ДП «Сторожинецьке ЛГ»)

Розподіл запасу деревини за ярусами є типовим для таких лісів: найвищі запаси притаманні першому, середні - другому, а найнижчі - третьому ярусу деревостану. Виняток становлять лише ялиновобуково-ялицевий квазіпраліс ДП «Делятинське ЛГ» - у цьому деревостані другий ярус представлений дрібними особинами, запас деревини яких ще незначний, тобто другий ярус тільки формується.
Подібну тенденцію щодо низького запасу деревини спостережено у третьому ярусі ялинового пралісу і букового квазіпралісу. Показники стану дерев у пралісах оцінювали за шістьма класами Міжнародної спілки лісових дослідних організацій (IUFRO): висоти (ярусності), життєвості, положення в ярусі, лісівничої функції, товарності, довжини крони (табл. 2). Згідно з отриманими даними, середній клас 
ярусності на об'єктах моніторингу пралісів змінюється в межах 1,70-2,42, з максимумом (найбільше дерев у третьому ярусі - 68\%) в ялиново-буковоялицевому квазіпралісі і мінімумом (найбільше де- рев в першому ярусі - 52\%) - в ялиновому пралісі. Отже, більшість досліджених деревостанів мають близьку до двоярусної структуру, а третій ярус представлений незначною кількістю дерев.

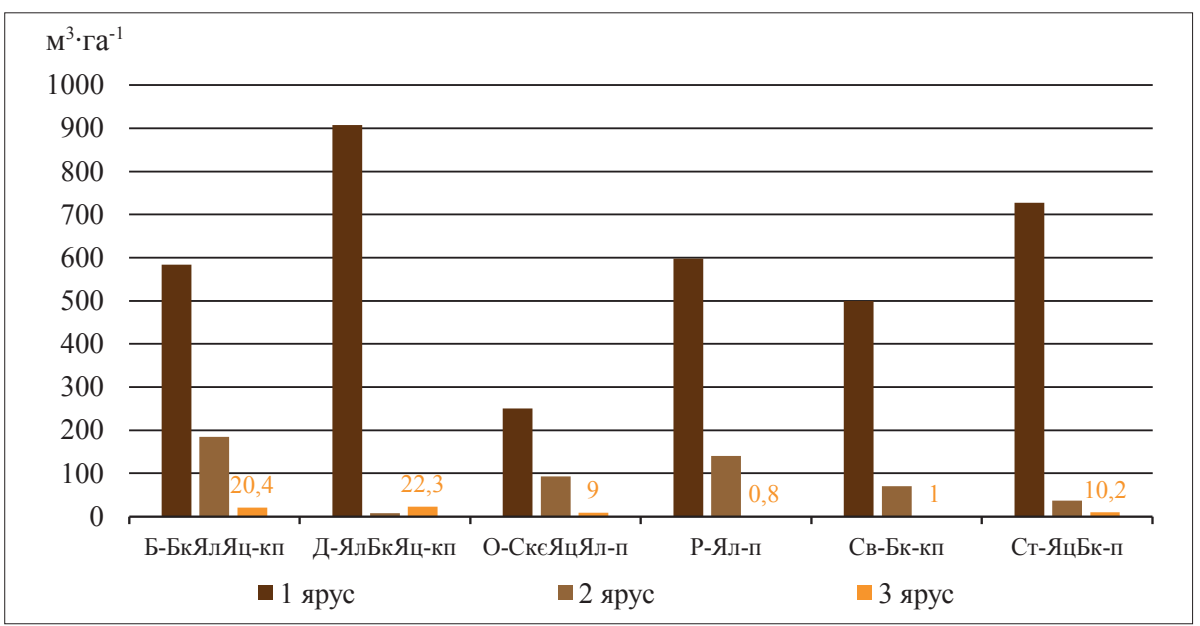

Рис. 6. Розподіл запасу стовбурової деревини за ярусами у деревостанах пралісів і квазіпралісів Українських Карпат

Середні значення класів IUFRO на об'єктах моніторингу пралісів

Таблиия 2

\begin{tabular}{lcccccc}
\hline \multirow{2}{*}{$\begin{array}{c}\text { Об’єкт } \\
\text { моніторингу }\end{array}$} & \multicolumn{7}{c}{ Класи IUFRO } \\
\cline { 2 - 7 } & ярусність & життєвість & $\begin{array}{c}\text { положення } \\
\text { в ярусі }\end{array}$ & функціональність & товарність & $\begin{array}{c}\text { протяжність } \\
\text { крони }\end{array}$ \\
\hline Б-БкЯлЯц-кп & 1,86 & 1,94 & 1,95 & 4,60 & 4,60 & 4,73 \\
Д-ЯлБкЯц-кп & 2,42 & 1,83 & 1,88 & 4,74 & 4,95 & 4,90 \\
О-СкєЯцЯл-п & 1,93 & 2,07 & 2,07 & 4,63 & 4,83 & 4,81 \\
Р-Ял-п & 1,70 & 1,52 & 1,74 & 4,33 & 4,44 & 4,22 \\
Св-Бк-кп & 1,71 & 2,00 & 1,90 & 4,71 & 5,10 & 4,52 \\
Ст-ЯцБк-п & 2,16 & 2,06 & 1,84 & 4,78 & 4,81 & 4,50 \\
\hline
\end{tabular}

Життєвість (середній клас життєвості) обстежених деревостанів переважно $є$ доброю (середній клас $\approx 1,9)$ і лише ялиновий праліс має життєвість, близьку до високої (59\% дерев). Такі результати виглядають неправдоподібними на фоні масового всихання ялини, однак, поряд 3 цим, $€$ підтвердженням результатів наукових досліджень у цьому напрямі - в Українських Карпатах масово всихають похідні ялинники, тоді як корінні поки що лише зменшили приріст за запасом деревини (Дебринюк, 2011; Shparyk et al., 2018). За положенням у конкретних ярусах переважають (69\%) домінантні дерева, тобто - без ознак пригнічення, і мінливість цього класу $\epsilon$ найменшою з усіх шести класів IUFRO.

Функціональність дерев у пралісах переважно добра (середній клас $\approx 4,6$ ), тобто не корисних 3 лісівничого погляду для функціонування пралісових екосистем дерев мало (12\%). Товарність дерев дещо гірша, ніж їхня функціональність (середній клас $\approx 4,8$ ), тобто в обстежених деревостанах переважають (52\%) придатні для окремих сортиментів (напівділові) стовбури. За протяжністю крони у пралісових угрупованнях найбільше дерев (45\%) із кронами середньої довжини, а 3 крайніх значень варто відзначити 78\% дерев 3 довгою кроною і повною відсутністю - 3 короткою кроною в ялиновому пралісі. Мертва лежача деревина, як один із основних індикаторів пралісових угруповань, $\epsilon$ на всіх об'єктах моніторингу і представлена відповідними ступенями розкладу. Ї̈̈ запаси також змінюються в значних межах (від 77 в буковому квазіпралісі до $533 \mathrm{~m}^{3} \cdot \mathrm{ra}^{-1}-$ у буково-ялиново-ялицевому), а деревні види відповідають типу лісу (рис. 7). Більшість об'єктів моніторингу за запасом мертвої лежачої деревини знаходяться в діапазоні 150-300 $\mathrm{m}^{3} \cdot \mathrm{ra}^{-1}$.

Розподіл запасу мертвої лежачої деревини за ступенями розкладу на більшості об'єктів моніторингу порушений - на них переважають перший i другий ступені розкладу, а не третій і четвертий, що властиво для пралісових угруповань. Цей аспект можна пояснити двома основними причинами: а) по-перше, на цей час деревостани перебувають на різних стадіях розвитку, їхній фактичний вік ще не досяг віку біологічної стиглості, що вно- 
сить певні корективи у розподіл мертвої лежачої деревини за ступенями розкладу; по-друге, всихання ялини європейської суттєво пришвидшилося за останні 10-15 років внаслідок зміни клімату (Дебринюк, 2011; FAO, 2016; Шпарик, Криницький, Дебринюк, 2020) і тому запас мертвої лежачої деревини ялини найбільший саме у проміжку першого і другого ступенів розкладу. Найближчим до класичного є розподіл запасу мертвої лежачої деревини за ступенями розкладу саме в ялиновому і ялицево-буковому пралісах. Наявність природного поновлення також $\epsilon$ обов'язковою умовою ідентифікації пралісів, квазіпралісів i природних лісів. Це підтверджено нашими дослідженнями 3 моніторингу пралісових угруповань - підріст представлений на всіх об'єктах моніторингу. Його кількість змінюється у значних межах (від 1 тис. шт. га ${ }^{-1}$ в ялиново-буково-ялицевому квазіпралісі до 108 тис. шт.'га ${ }^{-1}-$ в буковому квазіпралісі), а породний склад підросту відповідає типу лісу (рис. 8). Більшість об'єктів моніторингу за кількістю підросту знаходяться в діапазоні 5-20 тис. шт. га ${ }^{-1}$, що є достатнім для їх природного відновлення.

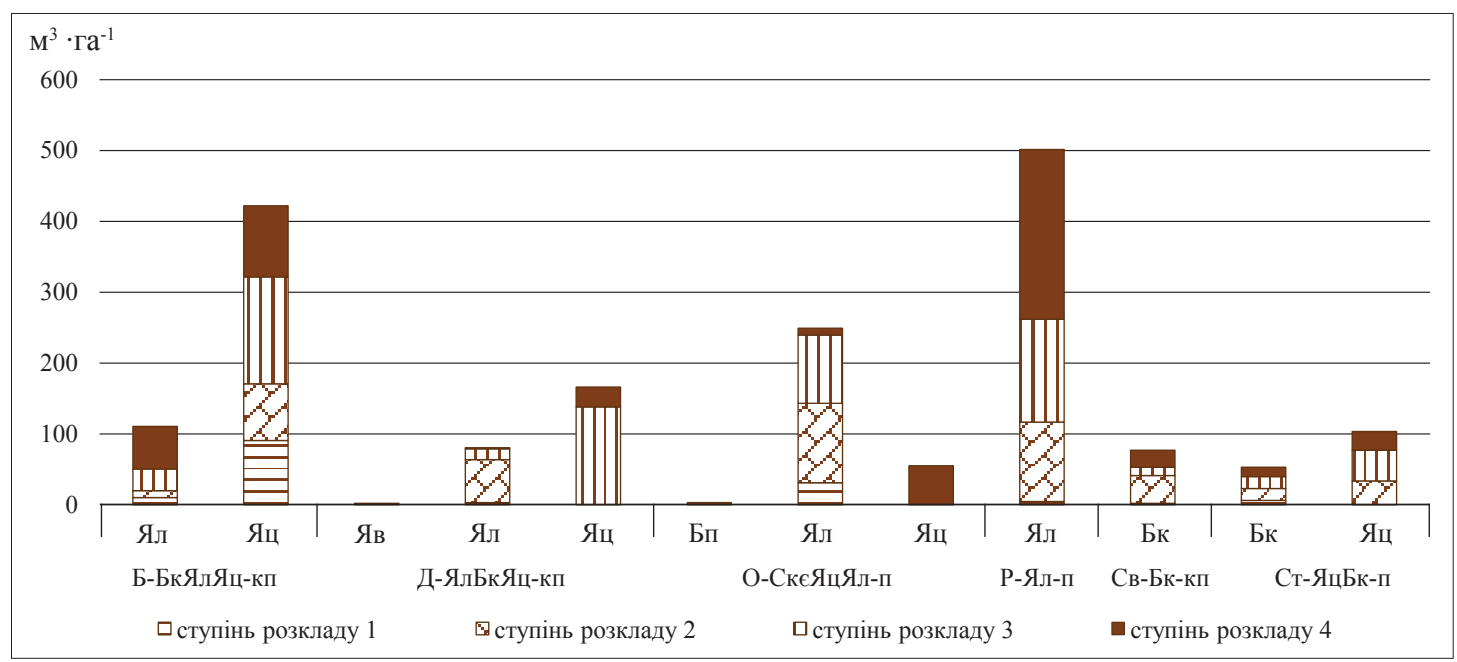

Рис. 7. Розподіл запасу мертвої лежачої деревини пралісів Українських Карпат за породами і ступенями розкладу

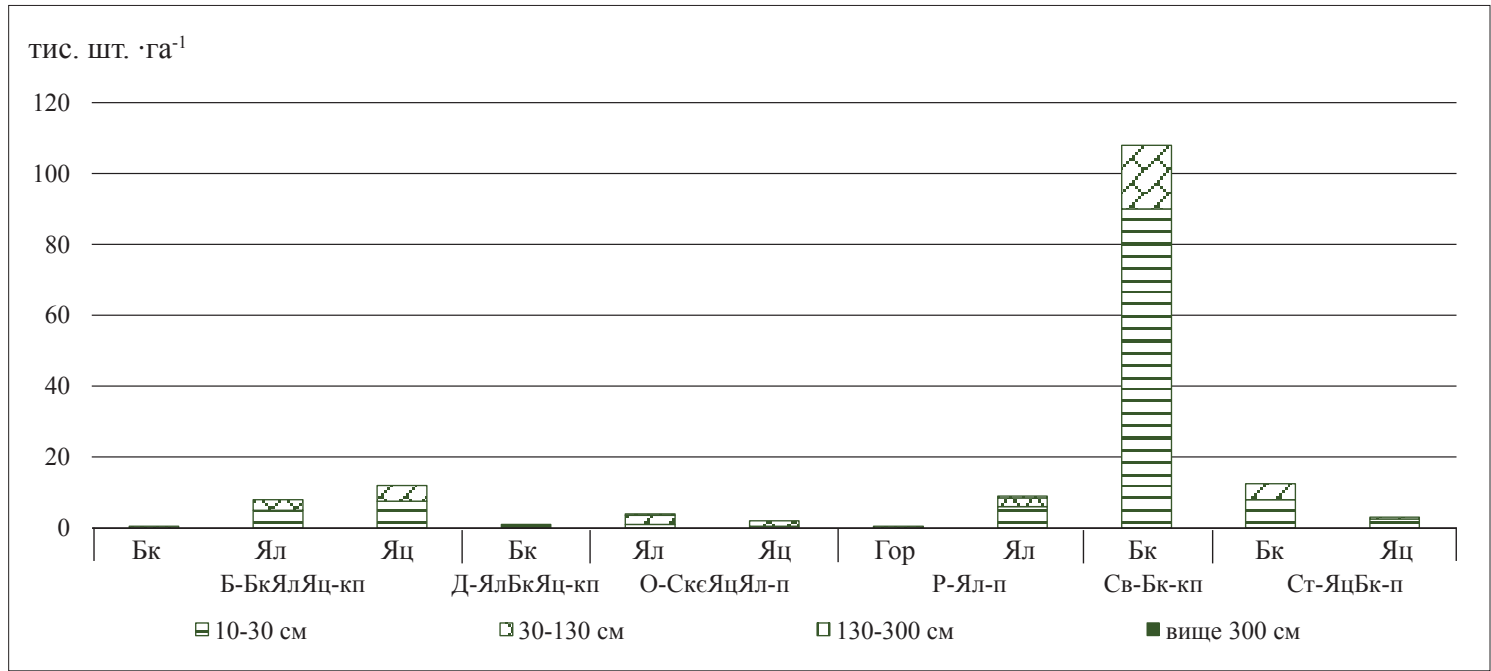

Рис. 8. Розподіл підросту пралісів Українських Карпат за породами і висотними групами

Розподіл кількості підросту за висотними групами на чотирьох об'єктах моніторингу відповідає класичному для пралісів - переважає дрібний (10$30)$ і середній (30-130) підріст, а кількість великого (130-300) і дуже великого (вище 300 см) - незначна. Однак негативним аспектом є відсутність окремих висотних груп підросту на всіх об'єктах моніторингу, зокрема, у кедрово-ялицево-ялиновому та у ялиновому пралісах відсутній дуже великий підріст, а в ялицево-буковому пралісі - дуже великий і великий підріст. У квазіпралісах переважно $є$ тільки дрібний і середній підріст, хоча в ялиновобуково-ялицевому квазіпралісі наявний лише дуже великий підріст. Отримані результати підтверджують наукові дані про високе різноманіття структури пралісів.

Унікальним видом робіт під час моніторингу пралісових угруповань $€$ контроль за рівнем антропогенного втручання в їхній розвиток. Відповідно до затвердженої методики ідентифікації пралісів, контролювали такі види цього впливу: здійснені чи заплановані лісівничі заходи, штучне лісовід- 
новлення, лісогосподарська інфраструктура, сліди рубань, заготівля недеревинних лісових продуктів, стан лісової підстилки, випасання худоби, рекреація та інші види. Згідно з отриманими результатами (табл. 3), основні види антропогенного втручання у пралісові угруповання Українських Кар- пат представлені стежками завширшки 0,7 i 1,0 м 3 витоптаною підстилкою, волоком завширшки 0,9 і завглибшки 0,4 м і старим волоком без підстилки, слідами рубань - два дерева без вивезення деревини, пилянням мертвої лежачої деревини без видалення, забрудненням пластиком.

Табличя 3

Рівень антропогенного впливу на об'сктах моніторингу пралісів

\begin{tabular}{|c|c|c|c|c|c|c|c|c|c|}
\hline \multirow[b]{2}{*}{$\begin{array}{c}\text { Назва } \\
\text { об’єктів } \\
\text { моніторингу }\end{array}$} & \multicolumn{9}{|c|}{ Рівень антропогенного впливу (відсутній, незначний, значний) за видами } \\
\hline & 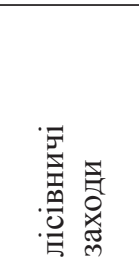 & 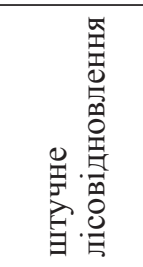 & 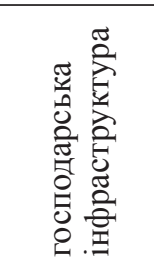 & 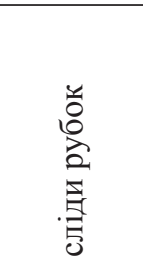 & 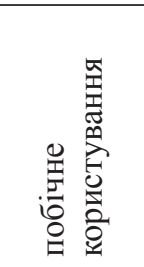 & 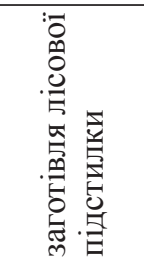 & 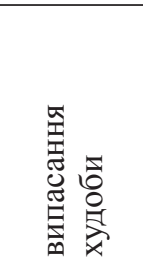 & 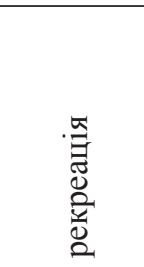 & $\begin{array}{l}\Xi \\
\Xi \\
. \Xi \\
. \Xi \\
. \Xi\end{array}$ \\
\hline Б-БкЯлЯц-кп & відсутні & відсутнє & незначна & відсутні & відсутнє & відсутнє & відсутнє & відсутня & відсутні \\
\hline Д-ЯлБкЯц-кП & відсутні & відсутнє & незначна & незначні & відсутнє & відсутнє & відсутнє & відсутня & відсутні \\
\hline О-СкєЯцЯл-п & відсутні & відсутнє & незначна & відсутні & відсутне & відсутнє & відсутнє & відсутня & відсутні \\
\hline Р-Ял-п & відсутні & відсутнє & незначна & відсутні & відсутнє & відсутнє & відсутнє & відсутня & відсутні \\
\hline Св-Бк-кп & відсутні & відсутнє & незначна & відсутні & відсутнє & відсутнє & відсутнє & відсутня & незначні \\
\hline Ст-ЯцБк-п & відсутні & відсутнє & відсутня & відсутні & відсутнє & відсутнє & відсутнє & відсутня & відсутні \\
\hline
\end{tabular}

Закономірно, що найінтенсивнішим є антропогенне втручання у пралісах, які розташовані поблизу великих населених пунктів: в ялиново-буковоялицевому квазіпралісі ДП «Делятинське ЛГ» (три види впливу), у буковому квазіпралісі ДП «Свалявське ЛГ» (два види впливу). Отже, моніторинг пралісів дав підставу ідентифікувати найпоширеніші в регіоні види антропогенного впливу: лісогосподарська інфраструктура присутня на 50\% об'єктів і представлена переважно старими волоками та лісовозними дорогами (на одному об'єкті - діючий волок); рекреація - на 33\% (стежки та забруднення території пластиком).

Під час досліджень також контролювали й інші структурні елементи пралісових екосистем: грунти, трав'яне вкриття, підстилку, мохи, лишайники, підлісок, фітоураження та ентомопошкодження дерев, кількість сухих дерев максимального діаметра. Грунти на дослідних об'єктах лише бурі лісові, але 3 різною скелетністю - від сильно щебенистого легкосуглинистого вологого мілкого світло-бурого (кедровоялицево-ялиновий праліс) до важко суглинистого свіжого глибокого темно-бурого з ознаками оглеєння (ялиново-буково-ялицевий квазіпраліс). Видовий склад трав' яного вкриття майже на всіх об' єктах відповідає типу лісу, за винятком кедрово-ялицевоялинового пралісу, де грунт і трав'яне вкриття однозначно підтверджують наявність вологого кедровосмерекового субору (за матеріалами лісовпорядкування - вологої чистої сусмеречини).

За результатами досліджень, у пралісових угрупованнях спостережено збільшення проективного вкриття мезоксерофітних видів рослин, стійкіших до недостатнього зволоження (Vaccinium vitis- idaea L., Luzula luzuloides Dandi et Wilmott). Також встановлено тенденцію до підняття вище в гори трав'яних видів букових лісів (Symphytum cordatum Waldst.et Kit., Circaea luferiana L.), які тепер постійно трапляються у смерекових типах лісу. Натомість, у букових та ялицево-букових лісах фіксують збільшення участі монтанно-рівнинних видів трав (Lycopodium clavatum L., Veronica officinalis L.), які зазвичай ростуть у свіжих лісорослинних умовах дубових лісів. Лісова підстилка є на всіх об'єктах моніторингу, однак лише типу «модер», а їі проективне вкриття змінюється від 10 до 60\%.

Різноманіття мохів і лишайників невисоке, але вони також присутні на всіх об'єктах моніторингу і їх види відповідають типу лісу. 3 фітопатологічних уражень найчастіше відзначена наявність справжнього й облямованого трутовиків та псевдоядра бука. 3 ентомологічних пошкоджень варто відзначити велику кількість видів короїдів та листогризучих шкідників. Сухі дерева максимального діаметра, як один з індикаторів під час ідентифікації пралісів, також наявні на всіх об'єктах моніторингу, а їхня кількість змінється від одного (буковий квазіпраліс) до 28-ми (буково-ялиново-ялицевий квазіпраліс). Підлісок, навпаки, переважно відсутній лише в ялиновому пралісі представлений окремими кущами бузини червоної. На об'єктах моніторингу пралісових угруповань також було здійснено фотофіксацію їхнього намету з висоти близько 100 м цифровою камерою, встановленою на спеціальному квадрокоптері (рис. 9). Можна чітко ідентифікувати нерівномірність намету (наявність прогалин) букового квазіпралісу Українських Карпат, яка формується внаслідок відмирання дерев пер- 
шого ярусу і поступовим заповненням утворених цим відмиранням прогалин деревами 3 підлеглих ярусів. Окремо зазначимо добрий стан букових лісів - ознаки дехромації виявлено лише на кронах окремих дерев.

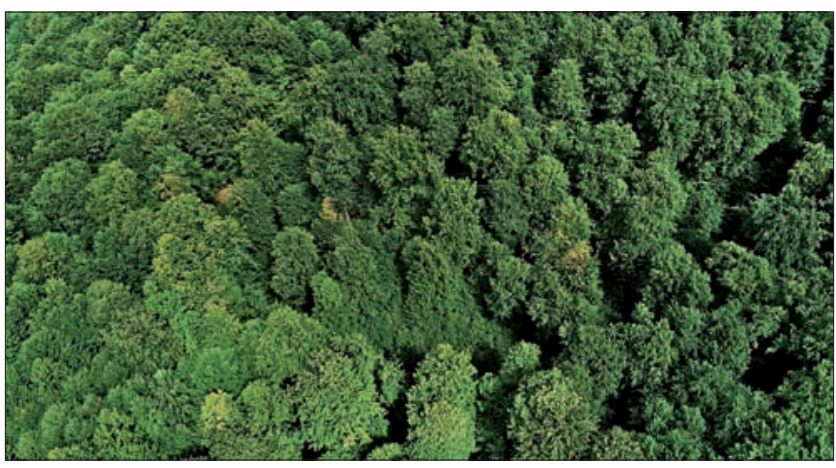

Рис. 9. Загальний вигляд букового квазіпралісу Українських Карпат з висоти «пташиного польоту» (фото М.В. Богомаза)

Зрозуміло, що в цій публікації неможливо навести детальний аналіз усіх результатів досліджень через значний обсяг отриманої інформації. Насамперед це стосується видового різноманіття трав, мохів, лишайників, шкідників лісу та пошкоджень дерев. Але продовження робіт з моніторингу пралісів дасть змогу не лише зібрати значний обсяг такої інформації, але й залучити до іiі аналізу кваліфікованих спеціалістів.

Висновки. Моніторинг пралісів Українських Карпат став результатом не тільки підвищеної уваги до цих природних угруповань науковців і громадськості, але й наслідком прийняття відповідних міжнародних та українських законодавчих нормативів. Реалізована на шести дослідних об'єктах у пралісах і квазіпралісах досліджуваного регіону методика моніторингу базується на затверджених методиках моніторингу лісів та ідентифікації пралісів.

Стан буково-ялиново-ялицевого квазіпралісу (ДП «Берегометське ЛМГ») характеризується середньою життєвістю дерев, високою їх товарністю i незначним антропогенним впливом, тоді як його структура - трьома ярусами деревостану, значною кількістю дерев та високим запасом деревостану, найбільшими запасом мертвої лежачої деревини та кількості підросту. Ялиново-буково-ялицевий квазіпраліс (ДП «Делятинське ЛГ») має інші показники стану - одна із найвищих життєвість дерев, найкоротша крона дерев, незначний, хоча й різноманітний, антропогенний вплив (сліди рубань, волок, забруднення пластиком) та структури - три яруси деревостану, висока кількість дерев, найбільші запаси стовбурової деревини, один із найменших запасів мертвої лежачої деревини і найменша кількість підросту. Для букового квазіпралісу (ДП «Свалявське ЛГ») характерні низька життєвість і найгірша товарність дерев, незначний антропогенний вплив, тоді як його структурі притаманні два яруси, найбільші діаметр і висота деревостану та кількість підросту, найменші кількість дерев і запас лежачої деревини та один із найменших запасів.

Кедрово-ялицево-ялиновий праліс (ДП «Осмолодське ЛГ») характеризується найгіршою життєвістю дерев та найкоротшими їхніми кронами, відсутнім антропогенним впливом, а його структура - трьома ярусами, найбільшою кількістю дерев, найменшими їх діаметром і висотою, найменшим запасом, малою кількість підросту, середнім запасом лежачої деревини. Ялиновий праліс (ДП «Рахівське ЛДГ») відзначається найкращими показниками стану - найвищими життєвістю, функціональністю і товарністю дерев, найкращим положенням i найдовшими кронами дерев, незначним антропогенним впливом. Поряд 3 цим, ялиновий праліс відзначається середніми структурними показниками двоярусністю, низькою кількість дерев (особливо - в другому і третьому ярусах), середнім запасом деревостану і кількістю підросту, одним із найбільших запасів мертвої лежачої деревини.

Стан ялицево-букового пралісу (ДП «Сторожинецьке ЛГ»), хоча й не зазнає антропогенного впливу, проте є одним із найгірших - 3 найнижчими функціональністю та життєвістю дерев, тоді як структура деревостану триярусна, близькими до середніх значень $\epsilon$ кількість дерев і підросту, запаси деревостану і мертвої лежачої деревини.

Загалом в обстежених пралісах і квазіпралісах Українських Карпат $є$ всі необхідні індикатори для ідентифікації таких лісів, добре сформоване лісове середовище і незначний антропогенний вплив на їх розвиток, тобто підтверджено дотримання підприємствами лісового господарства введених законодавством обмежень на здійснення заходів на цих лісових ділянках. Фактично єдиним видом впливу, який може викликати дискусію, є сліди рубань у квазіпралісах (прорубування стежок), але при цьому вилучення деревини з екосистеми не відбувалося. Наступним етапом моніторингу пралісів повинно стати наукове обговорення методик і результатів виконаних робіт, законодавче їх затвердження.

\section{Список літератури}

Алексеев Е. В. (1928). Типы украинского леса. Правобережье. Киев: КАИ, 120 с. [Alekseev, Е.V. (1928). Types of Ukrainian forest. Right bank of Dnipro River. Kiev: KAI] (in Russian)

Высоцкий Г.Н. (1916). О степном лесоразведении и степном лесоводстве. Киев: А.И. Гросман, 80 с. [Vysotsky, G. N. (1916). About steppe forestry and steppe forest management. Kiev: A. I. Grosman] (in Russian)

Дебринюк Ю.М. (2011). Всихання смерекових лісів: причини та наслідки. Науковий вісник Начіонального лісотехнічного університету України «Урбанізаційні процеси в гірських ландшафтах $i$ иляхи їхнього регулювання», 21(16), 32-38. [Debryniuk, Iu. M. (2011). Dieback of the spruce forests: causes and consequences. Scientific bulletin of the Ukrainian State Forestry University, 21(16), 32-38. 
Retrieved from http://nltu.edu.ua/nv/Archive/2011/21_16/ index21_16.htm] (in Ukrainian)

Докучаєв В.В. (1949). Наші степи колись $i$ mепер. Київ-Харків: Державне видавництво сільськогосподарської літератури УРСР. 140 с. [Dokuchaev, V. V. (1949). Our steppes then and now. KyivKharkiv: State Publishing House of Agricultural Literature of the USSR] (in Ukrainian)

Дідух Я.П., Чорней I.I., Буджак В.В. (2016). Кліматогенні зміни рослинного світу Украӥнських Kapnam. Чернівці: Друк Арт. 280 с. [Didukh, J.P., Chorney, I.I., \& Budzhak, V.V. (2016). Climatogenic changes in the plant world of the Ukrainian Carpathians. Chernivtsi: Druk Art] (in Ukrainian)

Калуцький І.Ф., Олійник В.С. (2007). Стихійні явища в гірсько-лісових умовах Українських Карпат (вітровали, паводки, ерозія грунту). Львів: Камула. 240 с. [Kalutsky, I. F., \& Olijnyk, V. S. (2007). Spontaneous phenomena in the mountain and forest conditions of the Ukrainian Carpathians (winds, floods, soil erosion). Lviv: Kamula, 240] (in Ukrainian)

Методика визначення належності лісових територій до пралісів, квазіпралісів і природних лісів. Затв. 18.05.2018 р., №161. Київ: Міністерство екології та природних ресурсів України [Methods for determining the affiliation of forest areas to virgin, quasi-virgin and natural forests. Kyiv: Ministry of Ecology and Natural Resources of Ukraine. Retrieved from https://zakon.rada.gov.ua/laws/show/z0707-18\#Text] (in Ukrainian)

Молотков П.И. (1966). Буковые леса и хозяйство в них. Москва: Лесная промышленность. 60 с. [Моlotkov, P. I. (1966). Beech forests and their management. Moscow: Forest industry] (in Russian)

Погребняк П.С. (1968). Общее лесоводство. Москва: Колос. 440 с. [Pogrebnyak P.S. (1968). General forestry. Moskow: Kolos] (in Russian)

Стойко С.M. (2006). Праліси як екологічні моделі для ренатуралізації вторинних фітоценозів. Украӥнський ботанічний журнал, 63(3), 358-368. [Stojko, S. M. (2006). Primary forests as ecological models of re-naturalization of secondary phytocoenoses. Ukrainskyj botanichnyj zhurnal, 63(3), 358-368] (in Ukrainian)

Шпарик Ю.С., Коммармот Б., Беркела Ю.Ю. (2010). Структура букового пралісу Українських Карпат. Снятин: Прутпринт. 143 с. [Shparyk, Y.S., Commarmot, B., \& Berkela Y.Y. (2010). Structure of the Ukrainian Carpathians beech virgin forest. Snjatyn: Prutprynt] (in Ukrainian)

Шпарик Ю.С., Криницький Г. Т., Дебринюк Ю. М. (2020). Тенденції динаміки типів лісорослинних умов і породного складу деревостанів Українських Карпат у зв'язку зі змінами клімату. Наукові праці Лісівничої академї наук України, 20, 82-92 [Shраryk, Y.S., Krynytskyy, H. T., \& Debryniuk, Iu. M. (2020). Trends of dynamics in the site conditions types and species composition of the forest stands of the Ukrainian Carpathians in connection with climate changes. Proceedings of the Forestry Academy of Sciences of Ukraine, 20, 82-92. https://doi.org/10.15421/412008] (in Ukrainian)
Шпарик Ю. С., Вітер Р.М., Шпарик В. Ю. (2020). Структурні зміни букового (Fagus sylvatica L.) пралісу в контексті кліматично орієнтованого лісівництва. Ukrainian Journal of Forest and Wood Science, 11(1), 87-97 [Shparyk, Y.S., Viter, R.V., \& Shparyk, V.Y. (2020). Structural changes of the common beech (Fagus sylvatica L.) virgin forest in the context of climate-smart forestry. Ukrainian Journal of Forest and Wood Science, 11(1), 87-97. http://dx.doi.org/10.31548/ forest2020.01.087] (in Ukrainian)

Biolley, H. (1901). Le Jardinage cultural. Journal Forest Suisse, 6(52), 97-104

Brang, P., Spathelf, P., Larsen, J.B., Bauhus J., Bončina A., Chauvin C. ... Svoboda M. (2014). Suitability of close-to-nature silviculture for adapting temperate European forests to climate change. Forestry, 87, 492-503. https://doi.org/10.1093/ forestry/cpu018

EUROPARC-España. (2017). Old-growth forests: characteristics and conservation value. Madrid: Fundación Fernando González Bernaldez

Engler, A. (1900). Wirtschaftsprincipien für die natürliche Verjungung der Waldungen mit besonderer Berucksichtigung der verschiedenen Standortsverhaltnisse der Schweiz. Schweiz. Z. Forstwes, 11-12, 264-275, 300-310. [Engler, A. (1900). Economic principles for the natural association of forestry with special support of the different standards of the Swiss. Swiss J. Foresters, 11-12, 264-275, 300-310] (in Germany)

FAO (2016). Global forest resources assessment 2015. How are the world's forests changing? Second edition. Rome: FAO. Retrived from http://www.fao. org/3/a-i4793e.pdf

Gayer, K. (1898). Der Waldbau. Berlin: Paul Parey. 626 p. [Gayer, K. (1898). Silviculture. Berlin: Paul Parey] (in Germany)

Gurnaud, A. (1886). La sylviculture française et la méthode du contrôle. Jacquin, Besançon. $121 \mathrm{~s}$. [Gurnaud, A. (1886). French forestry and the control method. Jacquin: Besançon] (in French)

Janda, P., Svoboda, M., Bače, R., Čada, V., Lynn, J., \& Peck, E. (2014). Three hundred years of spatio-temporal development in a primary mountain Norway spruce stand in the Bohemian Forest, central Europe. Forest Ecology and Management, 330(15), 304-311. https://doi.org/10.1016/j.foreco.2014.06.041

Jump, A. S., Hunt, J. M., \& Peñuelas, J. (2006). Rapid climate change-related growth decline at the southern range edge of Fagus sylvatica. Global Change Biology, 12, 2163-2174. https://doi.org/10.1111/ j.1365-2486.2006.01250.x

Korpel, S. (1995). Die Urwälder der Westkarpaten. Stuttgart, Jena, New York: G. Fischer, 310. [Korpel, S. (1995). The primeval forests of the Western Carpathians. Stuttgart, Jena, New York: G. Fischer] (in German)

Machar, I., Vozenilek, V., Simon, J., Pechanec, V., Brus, J., Fulnecek, P., \& Vitek, T. (2017). Joining of the historical research and future prediction as a support tool for the assessment of management strategy 
for European beech-dominated forests in protected areas. Nature Conservation, 22, 51-78. https://doi. org/10.3897/natureconservation.22.12902

Pittner, J., \& Saniga, M. (2008). A change in structural diversity and regeneration processes of the spruce virgin forest in Nefcerka NNR (TANAP) in relation to altitude. Journal of Forest Science, 54(12), 545-553

Schütz, J.-P., Saniga, M., Diaci, J., \& Vrška, T. (2016). Comparing close-to-nature silviculture with processes in pristine forests: lessons from Central Europe. Annals of Forest Science, 73(4). https://doi. org/10.1007/s13595-016-0579-9

Shparyk, Y.S., Berkela, Y.Y., Viter, R.M., \& Losiuk, V.P. (2018). Main types of forest stands dynamics in the Ukrainian Carpathians. Nature of the Carpathians, 1(3), 50-57. https://dx.doi. org/10.31548/forest2020.01.087

Shparyk, Y.S., Kagalo, A.A., Volosyanchuk, R.T., Savchyn, V.M., Berkela, Y.Y., Losyuk, V.P., \& Plyha, A. V. (2019). Implementation of research results on virgin forests in management practice of Ukraine. In Temperate and Boreal Primeval Forests in the Face of Global Change. Birmensdorf-Lviv

Shukla, P.R., Skea, J., Slade, R., van Diemen, R., Haughey, E., Malley, J., Pathak, M., \& Portugal P. J. (2019). Technical Summary. Climate Change and Land: an IPCC special report on climate change, desertification, land degradation, sustainable land management, food security, and greenhouse gas fluxes in terrestrial ecosystems. https://www.ipcc.ch/ site/assets/uploads/sites/ 4/2019/11/03_TechnicalSummary-TS.pdf

Standovár, T., \& Kenderes, K. (2003). A review on natural stand dynamics in Beechwoods of East Central Europe. Applied Ecology and Environmental Research, 1(1-2), 19-46. https://doi.org/10.15666/ aeer/01019046

WWF Ukraine (2019). Virgins and ancient forests. https://wwf.ua/our_work/forests/virgin_forests/.

WWF Ukraine (2021). Virgin, Quazi-virgin and Natural Forests of Ukraine. http://gis-wwf.com.ua/.

UNESCO (2007). Ancient and Primeval Beech Forests of the Carpathians and Other Regions of Europe. https://whc.unesco.org/en/list/1133/

Zenner, E. K., Lynn, J., Pecka, E., \& Hobi, M. (2020). Development phase convergence across scale in a primeval European beech (Fagus sylvatica L.) forest. Forest Ecology and Management, 460. https://doi. org/10.1016/j.foreco.2020.117889

Zlatník, A., Korsuň, F., Kočetov, F., Kseneman, M. (1938). Prozkum prirozených lesů na Podkarpatské Rusi. Sborník výzkumných ústavů zemědělských ČSR, sv. 152, Brno. 244 p. [Zlatník, A., Korsuň, F., Kočetov, F., \& Kseneman, M. (1938). Exploration of natural forests in Subcarpathian Russia. Proceedings of agricultural research institutes of the Czechoslovak Republic. 152] (in Czech)

\section{The state and structure of virgin forests in the Ukrainian Carpathians according to the monitoring results}

\author{
Y. Shparyk ${ }^{1}$, V. Losyuk², A. Plyha ${ }^{3}$
}

Last years' changes in the legislation on forest management in virgin, quasi-virgin and natural forests and the constant increase of the scientificfic and the public interest in the silviculture of virgin forest ecosystems have led to the identification of such forests and the natural monuments of virgin forests organization throughout Ukraine. The main part of this research and legislative work done within the framework of the of the World Wide Fund for Nature in Ukraine projects, according to which about 100 thousand hectares of such forests have already been identified, but these data are constantly updated. It was found that in these forests with 11 main species prevails Common beech $(58 \%)$ and Norway spruce $(33 \%)$, but Mountain pine (5\%) and Silver fir (3\%) are well represented too. These forests growth in 91 types of forest and biggest area have next: wet pure beech mesotrophic (18\%) and megatrophic (18\%) types, wet pure spruce mesotrophic $(13 \%)$ and cedar pine-spruce oligotrophic (6\%) types, wet beech-fir-spruce $(6 \%)$ and spruce-fir-beech $(5 \%)$ mesotrophic. Such significant diversity of forest types and types of forest stands in virgin, quasi-virgin and natural forests and the need to control the level of anthropogenic interference in their functioning determined the development of a new method of virgin forest monitoring based on the results of their scientific research and on the approved methods of forest monitoring and identification of primeval forests. The developed method tested in 2020 at six permanent plots in the Ukrainian Carpathians with the assistance of the World Wide Fund for Nature in Ukraine. Good conditions of these forests revealed (the best conditions had the spruce virgin forest and the worst - in the spruce-beech-fir quasi-virgin forest) and these forests had an insignificant anthropogenic impact (mainly infrastructure and recreation).

For example, spruce virgin forest has average forest parameters, but the best indicators of condition: a low number of trees (especially in the second and third layers), average wood volume and undergrowth number,

Yuriy Shparyk - Corresponding Member of the Forestry Academy of Sciences of Ukraine, Doctor of Agricultural Sciences, Professor, Department of Forestry. Vasyl Stefanyk Precarpathian National University, Galytska str., 201, Ivano-Frankivsk, 76008, Ukraine. Phone: + 38-0342-596163, + 38-050-188-02-61. E-mail: yurii.shparyk@pnu.edu.ua ORCID: https://orcid.org/0000-00018047-6356

Vasyl Losyuk - Corresponding Member of the Forestry Academy of Sciences of Ukraine, Candidate of Agricultural Sciences, Scientist. National natural park "Hutsulshchina", Druzhby str., 84, Kosiv, Ivano-Frankivsk region, 78600, Ukraine. Tel.: +380347823709 . E-mail: losyuk@i.ua ORCID: https://orcid.org/0000-0003-18071264

Andrii Plyha - forestry Expert, World Wide Fund for Nature in Ukraine, Raisa Okipnoj str., 4, office 170, Kiev, 02002, Ukraine. Tel.:+380637533767. E-mail: aplyha@wwf.ua 
one of the largest volume of the lying deadwood, the highest vitality, functionality and marketability of trees, the best position and the longest crown of trees, insignificant anthropogenic impact (old path up to $1 \mathrm{~m}$ wide). Spruce-beech-fir quasi-virgin forest has other characteristics: a high number of trees, the largest wood volume and the most complex structure, one of the largest volume of the lying deadwood and the smallest number of undergrowth, one of the highest vitality of trees, insignificant, albeit diverse, anthropogenic impact (cutting of trees, dragging way up to $0.9 \mathrm{~m}$ wide, pollution by plastic). Beech quasi-virgin forest has the biggest stand indicators (diameter and height), the smallest number of trees and volume of the lying deadwood, one of the lowest wood volume, the largest number of undergrowth, low vitality and the worst marketability of trees, insignificant anthropogenic impact (cutting of lying trees, old dragging way).

The necessity of annual monitoring of virgin forests from scientific and sozological positions to control their development and anthropogenic influence on these ecosystems has been substantiated.

Key words: main species; type of forest; type of stand; lying deadwood; natural regeneration; layered, vitality; functionality; marketability; crown length.

\section{Состояние и структура пралесов Украинских Карпат по результатам мониторинга}

\author{
Ю.С. Шпарык', В.П. Лосюк², А. В. Плыга
}

Последние изменения в законодательстве по ведению лесного хозяйства в пралесах, квазипралесах и природных лесах, постоянное повышение интереса ученых и общественности к лесоводственным особенностям девственных пралесных экосистем привели к идентификации таких лесов и выделении пралесовых сообществ на всей территории Украины. Основная часть этих научно-исследовательских и законотворческих работ сделана в рамках проектов ГС «Всемирный фонд природы Украина», по данным которых уже идентифицировано около 100 тыс. га таких лесов, но эти данные постоянно обновляются. Установлено, что в этих лесах с 11 главных пород преобладают Fagus sylvatica L. - 58 и Picea abies (L.) Karst. - 33\%, хорошо представлены Pinus mugo Turra - 5 и Abies alba Mill. - $3 \%$. Из 91 типа леса преобладают влажные чистая субучина $(18 \%)$ и бучина $(18 \%)$, влажная чистая сурамень $(13 \%)$ и влажная еловая суборь (6\%), влажные буково-пихтовая сурамень $(6 \%)$ и елово-пихтовая субучина (5\%).

Установлено, что значительное многообразие типов леса в пралесах, квазипралесах и природных лесах, потребность в контроле уровня антропогенного вмешательства в их функционирование обусловили разработку новой методики мони- торинга лесов на основе результатов научных исследований, утвержденных методик мониторинга лесов и идентификации пралесов. Разработанная методика апробирована в 2020 г. на шести объектах в Украинских Карпатах при содействии ГС «Всемирный фонд природы Украина». Выявлено хорошее состояние этих лесов - самое лучшее в еловом пралесе, худшее - в елово-буково-пихтовом квазипралесе с незначительным антропогенным воздействием на них (преимущественно инфраструктура и рекреация).

В частности, еловый пралес имеет средние таксационные показатели, но, наряду с этим, лучшие показатели состояния: низкое количество деревьев (особенно - во втором и третьем ярусах), средние запас древостоя и количество подроста, один из наибольших запасов мертвой лежащей древесины, самые высокие жизненность, функциональность и товарность деревьев, наилучшее положение и самую длинную крону деревьев при незначительном антропогенном воздействии.

Елово-буково-пихтовый квазипралес имеет совсем другие показатели: высокое количество деревьев, наибольший запас древостоя и наиболее сложная структура, один из самых больших запасов мертвой лежащей древесины и наименьшее количество подроста, одна из самых высоких жизненность деревьев, незначительное, хотя и разнообразное, антропогенное воздействие (следы рубок, волок, загрязнение пластиком). Буковый квазипралес имеет самые высокие таксационные показатели древостоя (диаметр и высота), наименьшее количество деревьев и запас мертвой лежащей древесины, один из самых низких запасов древостоя, наибольшее количество подроста, низкую жизненность и худшую товарность деревьев, незначительное антропогенное воздействие (следы рубок и старый волок).

Обоснована необходимость в ежегодном мониторинге пралесов с научных и созологических позиций для контроля за их развитием и за антропогенным вмешательством в эти природные экосистемы.

Ключевые слова: главная порода; тип леса; тип древостоя; мёртвая лежащая древесина; природное возобновление; ярусность; жизненность; функциональность; товарность; протяженность кроны.

\footnotetext{
Шпарык Юрий Степанович - член-корреспондент Лесной академии наук Украины, доктор сельскохозяйственных наук, профессор кафедры лесоведения. Прикарпатский национальный университет имени Васыля Стефаныка, ул. Галицкая, 201, г. Ивано-Франковск, 76008, Украина. Тел.: + 38-0342-596163, + 38-050-188-02-61. E-mail: yurii.shparyk@pnu.edu.ua ORCID: https://orcid.org/0000-0001-8047-6356

2 Лосюк Василий Петрович - член-корреспондент Лесной академии наук Украины, кандидат сельскохозяйственных наук, научный сотрудник. Национальный природный парк «Гуцульщина», ул. Дружбы, 84, г. Косов, Ивано-Франковская обл., 78600, Украина. Тел.: +03478-23709. E-mail: losyuk@i.ua ORCID: https://orcid.org/0000-0003-1807-1264

3 Плыга Андрей Викторович - координатор лесного направления, ГС «Всемирный фонд природы Украина», ул. Раисы Окипной, 4, офис 170, г. Киев, 02002, Украина. Тел.: +380637533767.E-mail: aplyha@wwf.ua
} 